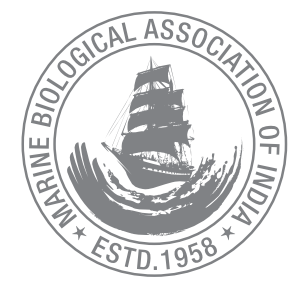

\title{
Differential exploitation of a single dominant prey species by migratory shorebirds - a preliminary observation from the vulnerable sandy beaches of the southwest coast of India
}

\author{
K. R. Aju ${ }^{* 1}$, Alvin Anto', K. M. Sreekumar, Molly Varghese and K. K. Joshi \\ ICAR-Central Marine Fisheries Research Institute, Kochi - 682 018. Kerala, India. \\ 'School of Marine Sciences, CUSAT, Kochi- 682 016, Kerala, India. \\ *Correspondence e-mail: ajukrajuifs@gmail.com
}

Received: 26 Oct 2019 Accepted: 24 Jan 2020 Published: 30 Jan 2020

Original Article

\begin{abstract}
Observations on the food resources of migratory shore birds in selected sandy shores of Kerala on the southwest coast of India revealed that their main prey resource is a single species of sand crab (mole crab), Emerita holthuisi Sankolli, 1965, the major crustacean resource in the narrow stretches of sandy shores of central Kerala. Three sandy beaches flanking tidal estuaries, abundant in shore crabs, were selected as the representative sites to study in detail the feeding of shorebirds on the sand crabs. We observed the presence of mole crabs for a year and noted that they are found almost year round on these shores. The shore birds were found to exploit them during their wintering months from October to February. The variations in adaptations of 8 species of predatory shore birds in preying on E. holthuisi were also noted. The same predator-prey relationship was observed in similar small stretches of sandy shores in other parts of central Kerala also.
\end{abstract}

Keywords: Shore birds, sand crab, Kerala, migration, sandy shore

\section{Introduction}

Shorebirds include a wide range of species that live in different types of shoreline habitats such as sand, rock and mudflats. They are predators, which feed on prey resources of the coastlines (Ferns, 2009). Their long legs, bills and agile movements help them survive in the shoreline and beaches that are highly dynamic by the action of waves and tides. A large number of shore birds migrate routinely in search of feeding grounds and fitting habitats, regulated by the seasons and the degree of intra and interspecific competition (Alerstam et al., 2003). The coasts and the coastal wetlands of Indian subcontinent serve as important stopovers and destination sites for numerous species of birds migrating from their Arctic breeding sites, along the Central Asian Flyway (CAF) (Henningsson and Alerstam, 2005). In Kerala, natural coastal wetlands cover around $25 \%$ of the total wetland area of the state. Submergent geographical features such as, lagoons and backwaters (Nair et al., 2018) and other habitats like mangroves, estuaries, mudflats, coastal swamps and seasonal paddy fields (Kokkal et al., 2008) in Kerala lie adjacent to the seashore and are connected to the sea through multiple river mouths. The proximity to the seashore makes these diverse habitats preferred by shorebirds, compared to the nearly barren sandy beaches. 
Sand crabs are one of the major biological components of the swash zone ecosystem and are highly adapted to live there by way of their rapid burrowing ability (Trueman, 1970). Emerita holthuisiare found abundantly in majority of the sandy beaches we monitored in central Kerala. Our observations were focused on three sandy shores in south and central Kerala such as Thottappally in Alappuzha, Puthuvype near Kochi, and Chettuva in Thrissur where sand crabs and their predatory waders were found commonly during the migratory season. No studies are hitherto published regarding the feeding preference of different shore birds on this abundant prey resource.

\section{Material and methods}

The study sites selected were three sandy beaches viz, Thottappally (9.3148N; 76.3801E), Puthuvype (10.0088N; 76.2158E) and Chettuva (10.5120N; 76.0356E), on the western side of Vembanad-Kol wetland, a Ramsar site in central Kerala (Fig.1). They are dissipative beaches having flat slopes and fine sands. Such beaches are usually poor in intertidal faunal diversity (Sivadas et al., 2012). All the three shores have adjacent estuarine and backwater systems and their position on the Central Asian-Indian flyway (Anon 1996; Mundkur, 2005) increase the significance of migratory shore birds. Thottappally has a small seasonal estuary formed by River Pamba. During the monsoon months the river enters the sea but later this connection is prevented when sand accretion during calmer periods restrict the flow. This accretion process regulates the extent of the beaches in Thottappally which usually has a shoreline in existence during the winter months. The estuary of Kochi is one of the largest in Kerala. It is perennial, whereby one main branch of the River Periyar enters the sea. Puthuvype shore

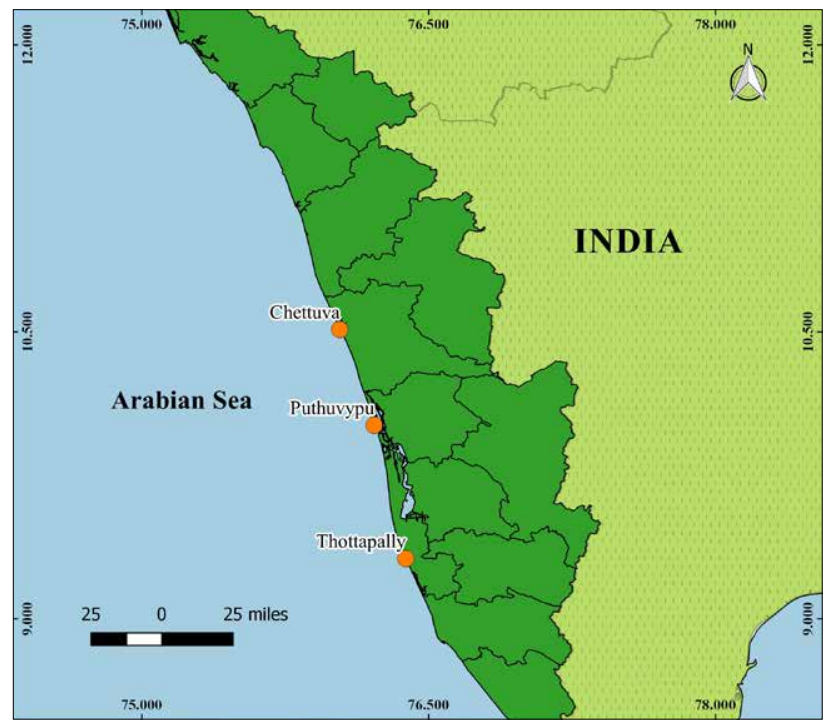

Fig. 1. Map of Study area is located on the northern side of this estuary, the extent of it is also determined by the monsoon erosion and later accretion. Chettuva is another small but perennial estuary formed by river Karuvannur, the northern part of it is a very small seasonal sandy shoreline.

Feeding pattern of shore birds was observed during the migratory season of 2018-19, over four months from October to January and observations were made in forenoon or afternoon. The number and diversity of the birds were recorded once every two weeks, making a total of eight observations. Special attention was paid to confirm whether the selected prey was sand crab (E. holthuisi), one of the dominant invertebrates in the region. We relied on photographs taken with a camera (Nikon D500 and Nikkor $200-500 \mathrm{~mm}$ lens) to confirm whether the prey on their bill was sand crab. The foraging patterns of eight selected waders namely Lesser Sand Plover, Kentish Plover, Common Greenshank, Whimbrel, Ruddy turnstone, Terek sandpiper and Black-bellied Plover were studied.

The sand crabs were randomly picked from different zones of the intertidal region to record the distribution pattern. Their burrowing depth was also noted. The individuals of varying size were collected for measuring their carapace length. The species was identified using morphological taxonomic keys, by examining under a (Leica) stereo microscope.

\section{Result and Discussion}

\section{Sand crabs}

The sand crab, E. holthuisi (Anomura, Brachyura, Hippidae) is a burrowing filter feeder found along the western coast of India up to Mumbai (Mahapatro et al., 2018). They form prominent aggregations and are major components of the macro fauna of sandy shores of the tropics and subtropics (Lastra et al., 2002). During the study period, i.e., post monsoon, egg carrying adults and juvenile crabs, were noticed probably indicating a year round recruitment of this species (Fig. 2). Another species of sand crab, Emerita asiatica was recorded farther south in the Kochi coasts of Kerala where they were found along the lower wave washed zone (Philip, 1974). There are no previous records on the presence of $E$. holthuisi on the Kerala coast north of Kochi. Simultaneously, we noticed the absence of $E$. asiatica in our study region.

The distribution of sand crabs across the shore exhibits vertical zonation. They are distributed largely across the mid-littoral zone. Within this zone the individuals were distributed based on their size. The larger crabs were found in the lower midlittoral part while the smaller ones, with decreasing order of size, were found towards the upper mid-littoral area. 


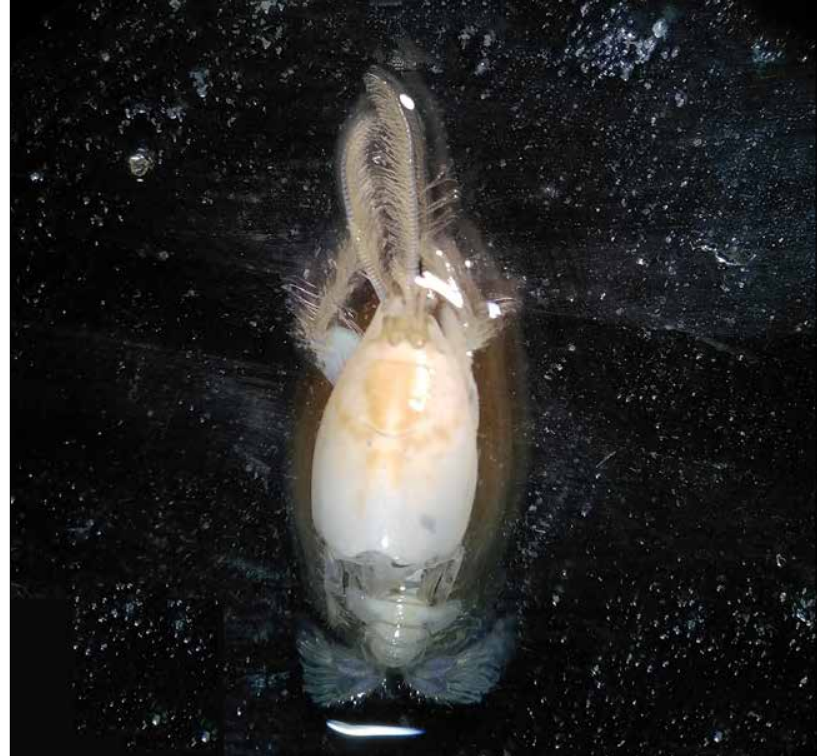

Fig. 2. E. holthuisi collected from the study area

\section{Shore birds}

The diversity and the number of these species were different in the three study locations so that the major predator of sand crabs in every location varied (Table 1).
Among the plovers sighted in the study area, Lesser Sand plovers (LSP) and Kentish plovers (Fig. 3) were found to be feeding intensely on sand crabs than other species. The Black-bellied Plover, (Pluvialis squatarola) did not choose sand crabs as prey of first preference. Though the shore was abundant with sand crabs the Black-bellied Plovers were found to be foraging for other prey items giving less preference to the sand crabs. Being a solitary predator (Baker, 1974), they were observed in very few numbers mostly at times when the beach was deserted of other shore birds.

Terek sandpiper was found to feed profusely on sand crabs. Ruddy turnstone is another non breeding migrant which is recorded in many coastal habitats across India (ebird, 2019). Though they are famous for turning stones while searching for food, the wintering individuals rely on other feeding methods based on the habitat types (Whitfield, 1990). In agreement with Whitefield's finding, only surface pecking and probing in the sandy beach was observed during the present study, which is a clear sign of the adoption of a different feeding technique with respect to the microhabitat where they feed. Crabs are the main intertidal prey resource for Whimbrels worldwide (Zwarts and Blomert, 1990). It is observed that they resort to tactile hunting whereby the prey was probed continuously and at depths. This, when adopted in the lower

Table 1. List of shore birds recorded from the study area in their order of decreasing abundance.

\begin{tabular}{lllc}
\hline SI. No & Species & No. of individuals observed & Thottappally \\
\hline 1 & Lesser sand plover (Charadrius sp.) & $>100$ & $\checkmark$ \\
\hline 2 & Kentish plover (Charadrius alexandrinus) & $50-100$ & $\checkmark$ \\
\hline 3 & Common greenshank (Tringa nebularia) & $20-30$ & $\checkmark$ \\
\hline 4 & Whimbrel (Numenius phaeopus) & $<20$ & $\checkmark$ \\
\hline 5 & Ruddy turnstone (Arenaria interpres) & $\checkmark$ & $\checkmark$ \\
\hline 6 & Terek sandpiper (Xenus cinereus) & $<20$ & $\checkmark$ \\
\hline 7 & Black-bellied plover (Pluvialis squatarola) & $<15$ & $\checkmark$ \\
\hline
\end{tabular}

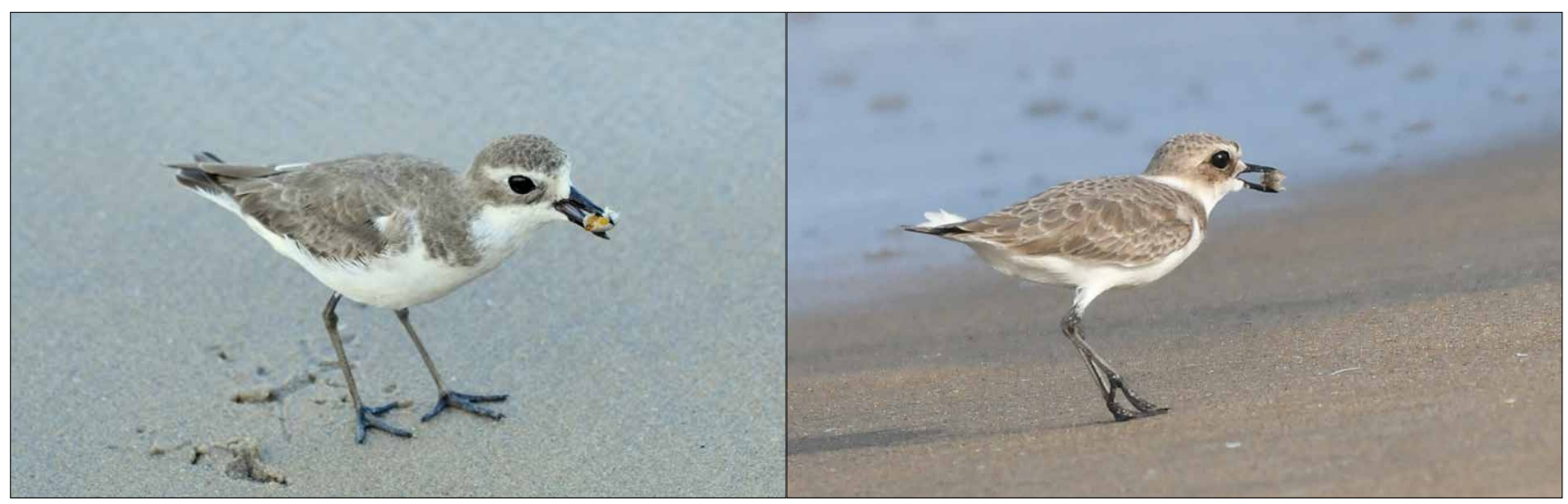

Fig. 3. Lesser Sand Plover (left) and Kentish Plover (right) with the sand crab 
mid-littoral zone expose larger sand crabs that seek shelter in more depths. Obviously, their longer bills and legs are adding more advantage to forage in this zone. Common Greenshanks too were found to feed in the lower mid-littoral, other than the upper littoral regions, aided by their long bills.

The foraging habits of birds depend on multiple factors such as the dispersion of prey, success in prey detection and capture, nutritional value of the prey, competition and threat of predation. They may prefer those sites where they can forage more quickly (Goss-Custard, 1970). In the case of waders the selection of a feeding patch and the actual foraging microhabitat within it depends on the social foraging behavior, the water level and prey availability (Maccarone and Brzorad, 2005).

It is noted that the upper limit of distribution of the sand crabs coincides with the upper wave mark. The sand crabs can burrow only in the wet saturated sand. So they dig as quickly as possible before the water drains from the soil (Trueman, 1970). As a result, the birds have to be quick in catching the crabs exposed for a short while after each wave recedes. The supra-littoral zone of our study area is too narrow for the birds to feed freely. Therefore, they have to be continuously on the lookout for waves and keep on running or flying so as to avoid getting drowned. Feeding in such a habitat demands more energy. In addition to this, the foraging success of the shore birds depends on their speed and the length of both limbs and bill.

The birds recorded in this study exhibited varying degrees of probing with their bills. The short billed species like plovers usually detect prey visually and pick them off while long billed ones probe deep into the sand (Fig. 4) (Lifjeld, 1984). We noted that the average burrowing depth of the mole crab was 2.0 $\mathrm{cm}$. The burrowing time of $E$. holthuisi is 1.5 seconds in coarse sediments (Lastra et al., 2002). On the upper end of the shore they dig deeper than in the lower margins as the interstitial spaces are less saturated with water in the upper sediments. Those hiding in the lower margin of wave action have to dig only shallow since the level of water saturation is high there. The waders having long bills were at an advantage here, as they could feed on the resources of the supra-littoral zone more easily than those having short bills. The three plover species with shorter bills had to probe deeply with their entire bill beneath the sand to get the crabs in the upper wash zones. At the same time their shorter legs restricted them from feeding on the lower zones where crabs could be pecked from minimum depth. The usual running behavior rather than flying of the plovers also demand more energy and time in feeding in such a habitat. The common greenshanks and whimbrels (Fig. 5) having both long bills and legs were found to be successful in catching the crabs from their burrows in the flood zone as

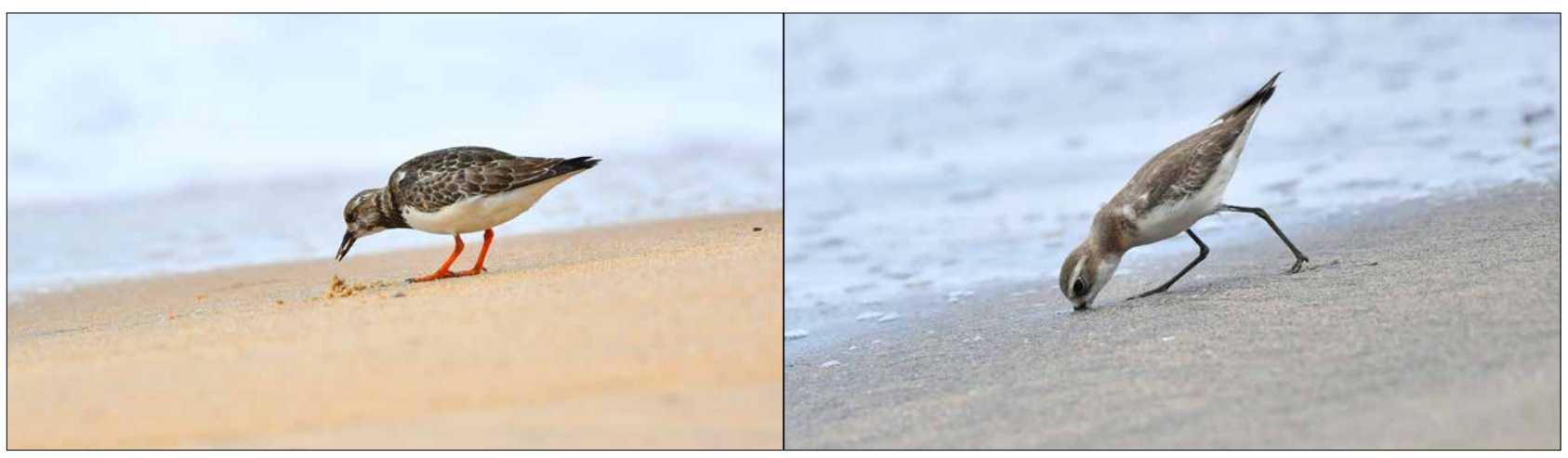

Fig. 4. The variation in the feeding mode of Ruddy turnstone (left) and Lesser sand plover (right).

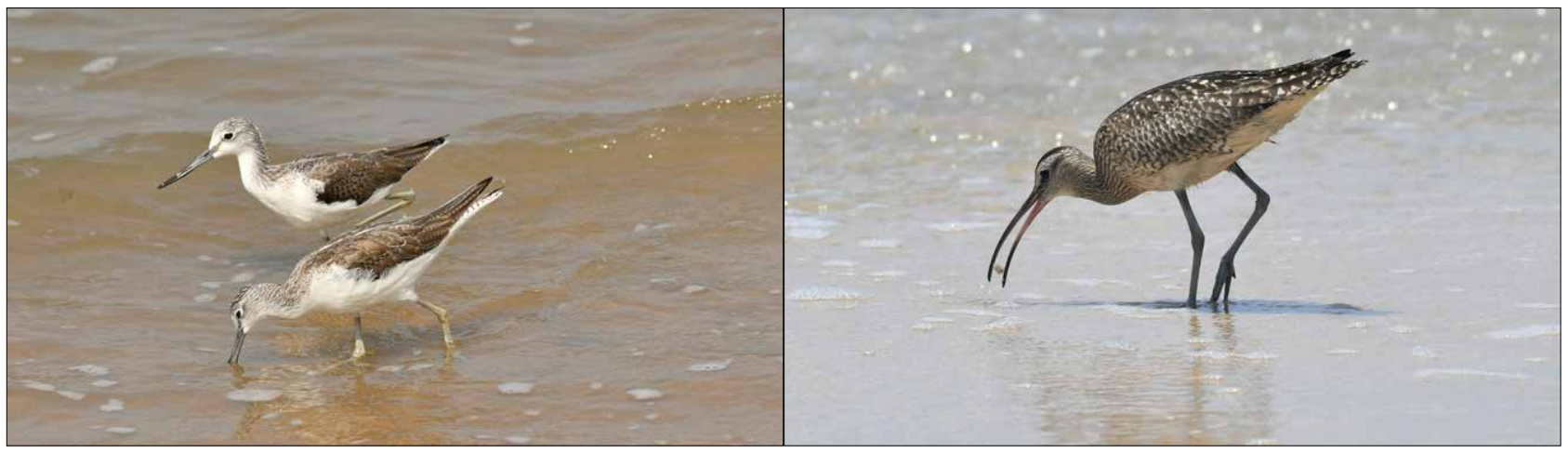

Fig. 5. Greenshanks (left) and Whimbrel (right) feeding in the lower littoral zone. 
well as in other zones. In the case of Terek sandpiper, despite the short legs, their long upwardly bent bills put them at an advantage in foraging the crabs on the supra-littoral zone more skillfully than the plovers and ruddy turnstones.

The selection of a habitat by an animal depends on various aspects of prey availability such as, abundance, distribution and timing of prey detection, capture and competition. Meanwhile, the occurrence of prey is determined by the habitat quality and nutrient availability (Maccarone and Brzorad, 2005). Our study locations were adjacent to tropical tidal estuaries fed by nutrient rich waters from the Western Ghats. They lie close to the highly productive Vembanad-Kol wetlands (VKW) and is located 0.5 to $1 \mathrm{~m}$ below mean sea level. The rivers discharging to these estuaries drain the VKW (Johnkutty and Venugopal, 1993). Waders that we recorded from the sandy shores could be seen in numbers in these wetlands where the abundant prey resources and the multiple microhabitats lessened the challenges they faced on the seashore. The ecological study of the birds in Kol by Jayson (2002) recorded waders, including the species observed in the present study, in hundreds except the ruddy turnstone which was comparatively rare. However, some species of waders observed during in the present study on the small stretches of sandy beaches were found feeding on E. holthuisi. Observations from the present study confirmed the presence of this sand crab on similar sandy shores of Kerala. The small population of waders found in those shores feeding on E. holthuisi confirms their preference for these small crabs. However, birds are largely restricted from exploiting this abundant prey because of the small size of beaches that are constantly subjected to anthropogenic pressures. The wave action and unpredicted shore erosion further prevents the birds from exploiting such a beneficial protein rich diet which would have been useful for their migratory behavior.

The feeding technique adopted by turnstone depends on a number of factors like the habitat, sex, prey, bill size and status as a competitor (Whitfield, 1990). The techniques adopted for a sandy beach such as probing and pecking behavior are observed in this study. As per Whitefield (1990), in the case of feeding competition the weaker ones are compelled to probe and peck instead of adopting the more energy efficient ways like routing in seagrass beds. In our study area, it was not competition as there were only a few individuals in the area, but the habitat type forced them to probe and peck. The plovers that frequent on the mudflats and paddy fields across Kerala feed on the abundant worm resources of such habitats (Aarif, 2009). At the same time their population across the sandy shores of the region confirms their adaptability to prey on the abundant single prey, the sand crab and thus evade competition. The feeding habits of LSP on the Kadalundy estuary (Aarif, 2009), around $80 \mathrm{~km}$ north of the present study sites are showed that polychaete worms seen on mudflats and mangroves were their major food resource outside sandy shores. The sandy beach near Kadalundy Estuary was rarely foraged by the birds because of the apparent absence of polychaete worms (Aarif, 2009). Our study site was also scarce in polychaete worms. This would have probably forced the birds to switch over to the next alternative prey source available in the area, i.e., the sand crabs. Feeding behavior of Terek sandpiper was studied in detail by Biljlsma and Roder (1991) and Piersma (1986). They feed almost exclusively on small crabs such as Uca sp. and Scopimera sp. There is high synchronicity in the feeding of Tereks and crab abundance. They prefer small crabs having a mean carapace width of 2.4 $\mathrm{mm}$ (Biljlsm and de Roder, 1991). The findings of the present study corroborate this observation, wherein the carapace width of the crabs collected from the study area was within the range of 2.00 to $8.00 \mathrm{~mm}$.

From this study, it was noted that intricate interactions between important physical and biological aspects determine the use of this sandy beach by the shorebirds. Firstly, though the availability of the prey resource is plenty, the birds cannot exploit it to the maximum because of the tidal and wave effects on the shore. The loss and accretion of shore due to wave action is a regular feature in this area. Secondly, the population of sand crabs was well established along the coast of Kerala and so even when some of the sandy shores were completely eroded, new population of sand crabs can colonize from other sites to the newly formed shores since their pelagic larvae can travel in currents (Sorte, 2001). Thus, the sand crabs are always replenished well in the shores flanking estuaries because of continuous nutrient input and gain significance as a readily available prey to the migratory birds. Finally, the low number of shorebird species and their small population size in a prey rich habitat points to multiple factors regarding the foraging behavior. Many other migratory waders tend to avoid this habitat not because of competition but due to the increased expenditure of energy and time needed for foraging in a tidal shore. At the same time, they were able to exploit the diverse prey bases of the adjacent paddy wetlands with much less expenditure of energy.

Narrow stretches of the sandy shores of Kerala can accommodate comparatively fewer numbers of waders than in the inland wetlands. The sandy beaches are heavily interrupted by seawalls, groynes and breakwaters (more than $75 \%$ of the $590 \mathrm{~km}$ shoreline), in addition to fish landing centers, tourist resorts and mangrove forests. These restrict the waders' distribution to isolated pockets of sandy beaches across the entire coastline. A healthy coastal zone is important in maintaining the nutrient cycles and prey resources for birds and fishes. They are Critical Transition Zones (CTZs) which are needed by different organisms 
for the completion of their life cycle (Levin et al., 2001). In case of sand crabs, the larvae are dispersed into the marine water later to invade the littoral zone as adults (Sorte et al., 2001). Thus sandy beaches are critical for feeding and breeding of sand crabs. Ansell et al. (1972) describes that the vertical zonation of the sandy shores of these regions diminishes to the minimum during the monsoon months and thus compress the distribution zones of the fauna. The extent of the present study areas are also under constant fluctuation. The months immediately after the monsoon witness the arrival of migratory birds as well as the sand accretion events to rebuild the shores. This spatial expansion of the shore facilitates the extension of the sand crab population thereby providing the migratory birds with plenty of resources though in a constrained habitat. For migratory shorebirds, these sandy beaches are critical feeding zones. Since the biogenic components of a sandy beach are low, the animal diversity of such a habitat depends on the nutrients of nearby ecosystems like estuaries (Sivadas et al., 2012). The estuary near the present study sites thus influences the faunal assemblages in the sandy shores nearby. A recent study by Nair et al. (2018) found that the study areas selected for the present study comes under the category of high erosion and moderate accretion. Besides the whole coast of Kerala is vulnerable to the annual monsoon storms and wave action which takes away the sandy shores, however, later accretion re-establishes the lost areas (Nair et al., 2018).

\section{References}

Aarif, K. M. 2009. Some aspects of feeding ecology of the lesser sand Plover Charadrius mongolus in three different zones in the Kadalundy Estuary, Kerala, south India. Podoces, 4: 100-107.

Alerstam, T., A. Hedenstro and A. Susanne. 2003. Long-distance migration: evolution and determinants. Oikos, 103: 247-260.

Ansell, D., B. Narayana, P. Sivadas, A. Trevalli and Vn. Sankaran. 1972. Ecology of two sandy beaches in southwest India .1. Seasonal-Changes in physical and chemical factors and in macrofauna. Mar. Biol., 17: 38-62.

Anon. 1996. Asia-Pacific Waterbird Conservation Strategy 1996-2000. Wetlands International Asia-Pacific, Kualalumpur, Publication No. 117, and International Waterfowl and Wetlands Research Bureau-Japan Committee, Tokyo

Baker, M. C. 1974. Foraging Behavior of Black Bellied Plovers (Pluvialis Squatarola). Ecology., 55(1): 162-167.
Biljsma, R. G. and F. E. Roder. 1991. Foraging behaviour of Terek Sandpipers Xenus cinereus in Thailand. Wader Study Gr. Bull., 61: 22-26.

eBird. 2019. eBird: An online database of bird distribution and abundance [web application]. eBird, Ithaca, New York. Website: http://www.ebird.org. (Accessed: May 20, 2019).

Ferns, P. N. 2009. Bird life of coasts and estuaries. Cambridge University Press.

Goss-Custard, J. D. 1970. The responses of Redshank (Tringa totanus (L.)) to spatial variations in the density of their prey. J. Anim. Ecol., 39: 91-113.

Henningsson, S. S. and T. Alerstam. 2005. Barriers and distances as determinants for the evolution of bird migration links: The arctic shore bird system, in: Proc. Royal Soc. B: Biol. Sci., 2251-2258.

Jayson, E. A., 2002. Foraging ecology of birds in Kole wetlands of Thrissur, Keral. KFRI Research Report No. 546 pp.

Johnkutty, I. and V. K .Venugopal. 1993. Kole Lands of Kerala. Kerala Agricultural University, Vellanikkara, Thrissur

Kokkal, K., P. Harinarayanan and K. K. Sabu. 2008. Wetlands of Kerala. In: Proceedings of Taal 2007: The 12th World Lake Conference. p. 889-1893.

Lastra, M., J. E. Dugan and D. M. Hubbard. 2002. Burrowing and swash behaviour of the Pacific mole crab Hippa pacifica (ANOMURA, HIPPIDAE) in tropical sandy beaches. J. Crustac. Biol., 22:53-58.

Levin, L. A., D. F. Boesch, A. Covich, C. Dahm, C. Erséus, K. C. Ewel, R. T. Kneib, A. Moldenke, M. A. Palmer, P. Snelgrove, D. Strayer and J. M. Weslawski. 2001. The function of marine critical transition zones and the importance of sediment biodiversity. Ecosystems, 4: 430-451.

Lifjeld, J. T. 1984. Prey selection in relation to body size and bill length of five species of Waders feeding in the same habitat. Ornis. Scand., 15: 217-226.

Maccarone, A. D. and J. N. Brzorad. 2005. Foraging Microhabitat Selection by Wading Birds in a Tidal Estuary, with Implications for Conservation. Waterbirds, 28: 383-391.

Mahapatro, D., S. K. Karna, S. K. Mohanty, B. Mohanty, P. R. Muduli, A. K. Pattnaik and S. Nanda., 2018. First record of a burrowing mole crab Emerita emeritus (Decapoda: Anomura: Hippidae) from Chilika Lake, east coast of India. Indian J. Geo-Marine Sci., 47: 109-113.

Mundkur, T. 2005. Building bridges for migratory waterbird conservation in the Central Asian Flyway. India Birds, 1: 46-47.

Nair, S. L., R. Prasad, M. K. Rafeeque and T. N. Prakash. 2018. Coastal morphology and long-term shoreline changes along the southwest coast of India. J. Geol. Soc., India, 92: 588-595.

Philip, K. P. 1974. The intertidal fauna of the sandy beaches of Cochin. In Proc. Indian Nat. Sci. Acad., B, 38: 317-328.

Piersma, T. 1986. Foraging behaviour of Terek Sandpipers Xenus cinereus feeding on sand-bubbling crabs Scopimera globosa. J. Ornithol., 127: 475-486.

Sankolli, K. N. 1965. On a new species of Emerita (decapoda, anomura) from India, with a note on Emerita emeritus (L.). Crustaceana, 8: 48-51.

Sivadas, S. K., B. Ingole, P. Ganesan, S. Sautya and M. Nanajkar. 2012. Role of environmental heterogeneity in structuring the macrobenthic community in a tropical sandy beach, west coast of India. J. Oceanogr., 68: 295-305.

Sorte, C. J. 2001. Larval dynamics of the sand crab, Emerita analoga, off the central Oregon coast during a strong El Nino period. J. Plankton Res., 23: 939-944.

Trueman, E. R. 1970. The mechanism of burrowing of the mole crab, Emerita. J. Exp. Biol., 53: 701-710.

Whitfield, D. P. 1990. Individual Feeding Specializations of Wintering Turnstone Arenaria interpres. J. Anim. Ecol., 59: 193-211.

Zwarts, L. and A. Blomert. 1990. Selectivity of whimbrels feeding on fiddler crabs explained by component specific digestibilities. Ardea. 78: 193-208. 